\title{
A Critique of the Abolitionist Approach to Regulate Prostitution in India
}

\author{
Aastha Bhandari
}

Student of Law, O.P Jindal Global University, Haryana, India

\begin{abstract}
This paper is based on the current approach of Indian law towards regulating prostitution in the country. It analyses the context in which sex workers in India are criminalized for their activities. Furthermore, it amplifies their vulnerable voices towards legislative bodies and calls for a decriminalization of prostitution in India. The article argues that there is a need for a change in India's abolitionist approach to regulating prostitution in the country. As such, the provisions of the IT(P)A need to be restructured as their anti- sex worker spirit is embodied in its every provision. The sex workers are perceived to be mere victims of prostitution through the lens of the law owing to the 'immoral' nature of their work. This further leads to their rejection as professionals providing services in the sex industry.
\end{abstract}

Keywords-prostitution, anti sex-worker, social inclusion, social stigmatization, IT(P)A, abolitionist, decriminalization.

\section{INTRODUCTION}

The practice of prostitution in India has been rooted in the archives of its history. Indian mythology comprises numerous references of high-class prostitution in the form of heavenly, mythical Goddesses indulging in the act of prostitution. "India is a land of contrasts where violence against women is rampant, where sexuality is celebrated in the erotic temple structures of Konark and in the ancient texts such as the Kamasutra (Art of Love) and there is widespread sexual repression and control over women's sexuality." (1, Gangoli) In third century A.D, religious prostitutes were connected to the well-known sanctuaries of Mahakala in Ujjain. They were given a place of honor in society. However, priests misused them to fulfill their own desires and a class of clandestine prostitutes was developed in India. Finally, in the era of the Mughal rulers, prostitution was recognized as a profession and the act had a strong nexus with the performing arts. After the downfall of the Mughal Empire, these prostitutes were ostracized by society due to the sudden social stigmatization of their profession. They faced economic duress and their pangs of hunger left them helpless at the hands of patriarchal male privilege. They were forced to turn to the trade of sex.

\section{APPRAISAL OF THE ABOLITIONIST APPROACH}

Today, prostitution still exists in the country. Prostitutes face the same level of financial insecurity along with the added fear of perpetrators of violence and the law does not stand to protect them. Thus, the question of how to conceptualize and regulate prostitution by law has led many countries to deliberate upon their vision of their prostitution policy. These visions range from regulative regimes for legalization of the sex industry to less interventionist models of decriminalization of sex work. Many of the regulative policies for sex workers across the globe have only increased the vulnerability of these beings to State, structural as well as societal violence. India follows the abolitionist approach to regulate prostitution in the country, whereby, buying and selling of sex is considered to be legal, however, surrounding activities like brothel-keeping or soliciting on the street are banned. In such an approach, the spotlight shines on the purchaser of commercial sex and in criminalizing his role in creating demand for the sex industry. This in turn pushes the entire system underground. Thus, such an approach provides only avenues for exit of the 'victims' of prostitution. Prostitution in India is presently regulated by the legal framework of the Immoral Traffic (Prevention) Act of 1956. This law forgets to make a distinction between voluntary and coerced prostitution. It punishes the unpopular minority groups in the country 
through its prohibitionist spirit. There is a need for a change in India's abolitionist approach to regulating prostitution in the country. As such, the provisions of the IT(P)A need to be restructured as their anti- sex worker spirit is embodied in its every provision. The sex workers are perceived to be mere victims of prostitution through the lens of the law owing to the 'immoral' nature of their work. This further leads to their rejection as professionals providing services in the sex industry.

The victim-like treatment of the sex workers in India has proven to be problematic. "A key rationale behind this is that prostitution is a central manifestation of male violence against women, which in turn means that those who sell sex are victims of prostitution."(Munro, 2) The law has conveniently created the binaries of victim and victimizers. "The law prioritizes the victim's exiting from the world of prostitution as the primary means of facilitating social inclusion. They are made to re-enter 'normal' society.'(Munro, 15) Notwithstanding, the law neglects to address the base of the issue. The reason for the allegedly abnormal and unethical existence of these sex workers was interceded to them by society. The interest for their use as mere sexual beings was created by society as a whole. . Their caste and class put them at the base of a dehumanizing hierarchical structure which determined their poor economic position. Financial insecurity of the sex workers remains to be the primary reason for prostitution to exist in India. If the sex workers are made to re-enter normal society, their economic position will force them to lapse back to the trade of sex. In this way the law forces you to keep selling sex, which is the exact opposite of its intended effect.

An estimated forty percent of India's population lives in poverty. Poverty does not create imbalances in gender and sex. It only aggravates existing imbalances in power and therefore increases the vulnerability of those who are at the receiving end of the gender prejudice. In a patriarchal set up, the section in families in societies that is affected is women and girl children. (Mirza, 3)

The Indian law fails to recognize that sex work is and always has been a survival strategy.

The very title of the IT(P)A intends to prevent immoral trafficking. It collapses the meaning of human trafficking and prostitution which creates a victim identity for the sex workers. According to s.2(g) of the Prevention of Immoral Traffic and the Rehabilitation of Prostituted Persons Bill of 1993, "Prostituted women means women who are victims of prostitution." Indian society believes that sex is primarily an instrument for reproduction and negates all aspects of its pleasure. Similarly, the IT(P)A does not give a social sanction to sex and sexuality beyond their reproductive purpose. According to section 2(a) of the IT(P)A, "brothel includes any house, room, or place which is used for purposes for the gain of another person or for the gain of two or more prostitutes." In simple terms, a brothel may be defined as two or more sex workers working together. According to section 3, running a brothel is punishable with imprisonment up to three years. Also, as per section 4, if any person over the age of eighteen years knowingly lives on a prostitute's earnings through prostitution, they would be subject to imprisonment for up to two years. The prostitutes who are caught indulging in the act are also made to pay fines. If the provisions of the IT(P)A are interpreted accurately they only reveal the true intentions of the law makers. In relevance to the various sections, a prostitute is forced to work alone as two prostitutes working together in a single space is punishable by law. This exposes the sex workers to abusive clients who may target them as law enforcement authorities do not stand to help these sex workers. Also, the husband and children of sex workers can be made punishable if they live on the earnings of prostitution. The fines pose a significant threat to the purpose of the IT(P)A. If a sex worker is caught selling sex in public, they are made to pay a fine. In order to pay these fines they need to go back out to the streets and offer their services to receive the necessary money. Law makers fail to comprehend that it was the need for money that got the sex workers to the street in the first place. The functioning of the IT(P)A enables the stacking up of fines and the sex workers are caught in a vicious cycle of selling sex to pay the fines which they initially got for selling sex.

There is a lamentable contrast between the lack of recognition of prostitution as a form of legislation and the economic discipline. The sex workers are not governed under the labor laws of the country as sex work is not a part of the occupation schedule of the Ministry of Labour in India. In reality, the sex workers do practice an occupation and meet a social demand for sex. Illegal commercial sex poses a great level of harm to the sex workers. Usually, sexually exploited people who enter the illegal sex trade as minors, are coerced into prostitution by pimps and traffickers, and are often victims of violent crimes by various dominant parties. Abduction is the most common cause of entry of sex workers into the market of prostitution. The Indian government estimates that there are about three million sex workers in India. A trafficked person who is coerced to fall in the trade of sex cannot be called a sex worker. Sex workers are extremely vulnerable to abuse and exploitation by various parties as they cannot 
find recourse through law. They are subjected to abuse by law enforcement authorities like police officers. Law makers do not register that all attempts to control or prevent sex work from happening makes things more dangerous for the people selling sex. In such circumstances, it is the need of the hour to recognize prostitution as a legitimate profession and regulate it using business and labour laws instead of criminal laws. The illicit market needs to be brought out from the underground.

The regulative policy of the nation of $\mathrm{New}$ Zealand of decriminalization has proven to be one of the most beneficial models for the rights of sex workers.

Prior to the passing of the Prostitution Reform Act of 2003, New Zealand followed the abolitionist approach to regulate prostitution. Presently, the exercises related with prostitution have a decriminalized status. Brothels are governed by the general employment and health regulations in the country. Soliciting has also been decriminalized. The new law distinguishes between voluntary and coerced prostitutionLaws that clearly distinguish between sex work and crimes like human trafficking and sexual exploitation of children help protect both sex workers and crime victims. Contracts between provider and client are recognized and the provider can refuse services. (Munro, 2)

They have the right to safe and fair working conditions as well as the right to social security and old age pensions.This system has the benefits of having policeprotection, the ability to build a community with other sex workers and obtaining rights as workers. This Act was passed after consultation and deliberation with the prostitute's collectives in New Zealand and thus caters to their basic needs. The Act has been effective in achieving its purpose of reducing the vulnerability of sex workers to abusers, ensuring their safety and health as well as providing them labour and human rights.

The main argument against decriminalization of prostitution is that the act is immoral in nature and thus all measures should be guided to prohibit it in society and eradicate it. Also, prostitution is a highly controversial issue. An amendment to the law would not be welcomed by the Indian society. However, this argument only goes to show the double standards of our society. Supply will only exist when there is a demand for a particular commodity or service. Sex workers face social stigmatization and alienation. Their work is deemed to be immoral. However, the buyers of sex, predominantly being male, who create the demand for these sex workers are not targeted or punished by the same society. Men are perceived to have certain essential sexual needs which need to be fulfilled at the hands of the sex workers. An exceptional example of this would be the release of the Deepa Mehta's Indian film 'Water' in 2005. It faced severe backlash as the guardians of India's morality were quick to respond. The film documented the lives of widows at an ashram in Varanasi. "It was not a film about widow prostitution. It was supposed to be a love story shaped by modernity." (Ghosh, 1) However one of the protagonist widows in the film was shown to indulge in prostitution for the benefit of the ashram. Indian society saw these religious widows as icons of honor and was provoked at the thought of their clandestine prostitution even though such a reality existed. Their double standards discriminate the immorality of a particular act on the basis of one's gender.

India's current approach to the regulation of prostitution is vividly not effective in dealing with basic issues like the safety, health, human rights as well as professional rights of the sex workers.

" Based on the experiences of women in prostitution, as this opinion of the criminal justice system from a woman in the trade brings out: 'They do not consider us as human beings. They add to our harassment and humiliation. They fail to understand the human aspects of the problem. They perceive it as a law and order problem."( qtd in Gangoli 19)

\section{CONCLUSION}

Sex work should be seen as a profession by the law makers of the country. They should consciously make an effort to ensure that the meaning of sex work and trafficking is not conflated through law. The abolitionist approach to eradicate the very existence of prostitution has proven to beuseless as prostitution has continued to exist since the British colonial era. Today, sex workers should be in a position to regulate their own business and stand together as a community against the perpetrators of violence. Legislation needs to comprehend their basic human rights and not deem them to be simply 'immoral.' There is a need for India to adopt the approach of decriminalization of prostitution in the country, whereby, there would be regulatory boards and legally recognized sex worker forums which would regulate the entry and exit of sex workers in the profession. The constant victimlike treatment needs to be done away. "Special laws must be enacted to recognize and redress the historical disadvantage women in sex work have suffered as a result of social stigma and denial of legal rights."( qtd in Gangoli 20). Legal machinery should attack the reasons 
for entry into prostitution, not the sex workers themselves. Prostitution laws should cater to the needs and problems of the sex workers in India and as such should be made with consultation and deliberation with sex worker collective groups. Law stands to protect the sex workers not suppress them and its anti sex-worker spirit needs to be done away with.

\section{ACKNOWLEDGEMENTS}

I would like to thank my family for the constant support and inputs on my research as well as writing. Furthermore, I would like to thank my peers for their critique of this paper.

\section{REFERENCES}

[1] Ghosh, Swati. "Bengali Widows of Varanasi." Economic and Political Weekly Vol 35. No.14 (2000): pp 1151-1153. JSTOR. Web. 25/04/2020.

[2] Gangoli, Geetanjali. "Prostitution in India: Laws, Debates and Responses.” International Approaches to Prostitution: Law and Policy in Europe and Asia, edited by Geetanjali.

[3] Gangoli and Nicole Westmarland, 1st ed., Bristol University Press, Bristol, 2006, pp. 115-140. JSTOR. Web. 25/04/2020.

[4] Munro, Vanessa E, and Marina Gusta. Demanding Sex: Critical Reflections on the Regulation of Prostitution. London: Ashgate, 2008. Print

[5] Mirza, Abbas. Pantyless Nights: Lives of Sex Workers. India: Abbas Mirza, 2014.

[6] The Immoral (Traffic) Prevention Act of 1956. https://indiacode.nic.in/bitstream/123456789/1661/1/19561 04.pdf 